\title{
Diacylglycerol kinase a promotes 3D cancer cell growth and limits drug sensitivity through functional interaction with Src
}

\author{
Pedro Torres-Ayusoํㅜ, Manuel Daza-Martínㄹ, Jorge Martín-Pérez², Antonia Ávila- \\ Flores $^{1}$ and Isabel Mérida ${ }^{1}$ \\ ${ }^{1}$ Department of Immunology and Oncology, Centro Nacional de Biotecnología/CSIC, Madrid, Spain \\ 2 Department of Cancer Biology, Instituto de Investigaciones Biomédicas Alberto Sols/CSIC, Universidad Autónoma de \\ Madrid, Madrid, Spain \\ Correspondence to: Antonia Ávila-Flores, email: jaavila@cnb.csic.es
}

Isabel Mérida, email: imerida@cnb.csic.es

Keywords: Diacylglycerol kinase, Src, 3D tumor growth, chemotherapy resistance, PI3K/AKt

Received: August 05, $2014 \quad$ Accepted: August 11, $2014 \quad$ Published: August 12, 2014

This is an open-access article distributed under the terms of the Creative Commons Attribution License, which permits unrestricted use, distribution, and reproduction in any medium, provided the original author and source are credited.

\section{ABSTRACT}

Diacylglycerol kinase (DGK)a converts diacylglycerol to phosphatidic acid. This lipid kinase sustains survival, migration and invasion of tumor cells, with no effect over untransformed cells, suggesting its potential as a cancer-specific target. Nonetheless the mechanisms that underlie DGKa specific contribution to cancer survival have not been elucidated. Using three-dimensional (3D) colon and breast cancer cell cultures, we demonstrate that DGKa upregulation is part of the transcriptional program that results in Src activation in these culture conditions. Pharmacological or genetic DGKa silencing impaired tumor growth in vivo confirming its function in malignant transformation. DGKa-mediated Src regulation contributed to limit the effect of Src inhibitors, and its transcriptional upregulation in response to PI3K/Akt inhibitors resulted in reduced toxicity. Src oncogenic properties and contribution to pharmacological resistance have been linked to its overactivation in cancer. DGKa participation in this central node helps to explain why its pharmacological inhibition or siRNA-mediated targeting specifically alters tumor viability with no effect on untransformed cells. Our results identify DGKa-mediated stabilization of Src activation as an important mechanism in tumor growth, and suggest that targeting this enzyme, alone or in combination with other inhibitors in wide clinical use, could constitute a treatment strategy for aggressive forms of cancer.

\section{INTRODUCTION}

The diacylglycerol kinases (DGK) phosphorylate diacylglycerol (DAG) to produce phosphatidic acid (PA); DGK thus regulate the levels of two lipids with key roles in signaling and metabolic pathways [1]. Many reports support a positive role for the DGKa isoform in cancer progression. This lipid kinase assists tumor survival [24], migration and invasion [5-7]. DGK $\alpha$ expression is increased in tumors compared to adjacent non-cancerous tissue [3,4], as well as in metastasis of the original tumor $[8,9]$. When mutated, it is a causative gene in pancreatic cancer [10], and was recently described as a potential target for glioblastoma treatment [11]. Nonetheless, the mechanisms by which DGK $\alpha$ contributes to these processes, and the exact tumor context for which DGK $\alpha$ is an effective target have not been elucidated.

DGK $\alpha$ function is regulated by transcriptional and post-transcriptional mechanisms. Distinct routes converge and are integrated at the $D G K \alpha$ gene promoter region, including those of PI3K/Akt/FoxO, p53 and Ras [12-14]. DGK $\alpha$ is a cytosolic enzyme, and its phosphorylation by distinct members of the Src family kinases (SFK) lead to its recruitment to the plasma membrane and activation [15-18]. SFK are non-receptor tyrosine kinases that share a common modular structure including a SH3 and a SH2 domains involved in protein interactions, and a myristoylation site at the $\mathrm{N}$-terminus for membrane targeting [19]. In vitro experiments with GST (glutathione S-transferase)-purified DGK $\alpha$ and recombinant $\mathrm{Src}$ 
mapped DGK $\alpha$ interactions with $\mathrm{Src} \mathrm{SH} 2$ and $\mathrm{SH} 3$ regions [18].

Src is the most widely expressed member of the SFK family and is relevant in many cancer types, since it controls tumor cell proliferation, survival, migration and invasion $[20,21]$. Src regulates mitogenic and survival signaling cascades downstream of receptors tyrosine kinase (RTK), which are frequently mutated and/or overexpressed in breast and colon cancer. Oncogenic Src functions are also related to its activation downstream of integrins to regulate survival and invasion [22]. Src activity is predictive of poor clinical prognosis in colon and pancreatic cancer $[23,24]$. These findings have led to substantial efforts to test the therapeutic potential of Src inhibitors in advanced cancers such as breast and colon, which are very frequent tumor types and tend to present early relapse and metastasis. Although preclinical evidence supported the use of such inhibitors, its therapeutic effectiveness as single agents in clinical assays for solid tumors has been discouraging [25]. This is probably due to incomplete knowledge of the mechanisms that control Src transforming potential and of the cancerrelated Src-regulated pathways. Src is involved in many fundamental cellular processes, but the Src deficient mice are viable [26]. In contrast to viral oncoproteins, Src alone is insufficient to transform cells in vitro, and activating mutations of SFK are rarely observed in cancer $[27,28]$, suggesting further control by specific Src regulators that promote or restrain its tumorigenic properties [29, 30].

Here we tested the hypothesis that DGK $\alpha$ expression in tumor cells contributes to oncogenic SFK functions. We analyzed the DGK $\alpha$ contribution to breast and colon cancer in $3 \mathrm{D}$ cell cultures. These culture conditions closely mimic the in vivo cell environment and have been used to demonstrate the activation of transcription programs that lead to tumor survival and drug resistance [31-33]. Tumor cell growth in 3D culture is particularly dependent on integrin and Src signaling cascades, a property that it is not recapitulated in 2D conditions nor in non-transformed cells [34]. We found that DGK $\alpha$ silencing or inhibition prevented cancer cell growth in 3D culture as well as tumor growth in vivo. Analysis of DGK $\alpha$ expression and Src activation under 3D conditions provided a mechanistic link by showing that DGK $\alpha$ expression has a positive regulatory function in Src activation. DGK $\alpha$ contribution to this central node helps to explain why targeting of DGK $\alpha$ specifically alters tumor viability, with no effect on untransformed cell survival. We identified DGK $\alpha$ as a Src-interacting partner that is necessary to sustain Src signaling and whose targeting improved the effect of Src and PI3K/Akt inhibitors. Our findings indicate that DGK $\alpha$ might be an effective target for anti-cancer therapies, alone or in combination with other widely used inhibitors.

\section{RESULTS}

\section{DGKa is necessary for cancer cell growth in 3D culture}

DGK $\alpha$ has been studied in several cancer models, where experimental evidence has shown that it mediates various aspects of cancer cell progression. No studies have addressed the contribution of this isoform to colon cancer so we selected the SW480 cell line, which was derived from a primary colorectal tumor and shows characteristics of highly transformed cells. The contribution of DGK $\alpha$ to the tumoral properties of SW480 cells was addressed by reducing its expression using interferent RNA. Previous validated DGK $\alpha$ target sequence $[35,36]$ efficiently reduced the expression of the protein in SW480 cells (Fig. S1A). Expression of DGK $\zeta$, an isoform that complements some DGK functions in T lymphocytes, was not altered in DGK $\alpha$ silenced cells (Fig. S1A). To evaluate the contribution of DGK $\alpha$ during long-term culture, the targeting sequence was cloned as shRNA in the pSuperRetro vector; this was then used to generate cells with stable reduction of DGK $\alpha$ levels (Fig. S1B).

The effect of DGK $\alpha$ downmodulation on longterm growth of SW480 cells was evaluated in matrigel $3 \mathrm{D}$ culture and on plastic, $2 \mathrm{D}$ culture conditions. In 3D culture, SW480 cells showed a disorganized structure with poor cell-cell contacts, characteristic of highly transformed tumors [37]. Reduced DGK $\alpha$ expression in 3D cultures of the stably downregulated SW480 cells was corroborated by immunofluorescence (Fig. 1A). When compared to their control counterpart, cells with reduced DGK $\alpha$ levels formed smaller colonies (Fig. 1B). DGK $\alpha$ attenuation impaired cell proliferation, as revealed the reduced number of cells incorporating EdU (5-ethynyl-2 deoxyuridine), a thymidine analogue that measures DNA synthesis (Fig 1C).

Reduction of DGK $\alpha$ protein levels did not significantly affect cell growth in 2D; these cells formed colonies at the same extent that control cells (Fig. S2A). The effect of reduced DGK $\alpha$ expression on cell growth in either $2 \mathrm{D}$ or $3 \mathrm{D}$ conditions was compared by measuring cell viability with a tetrazolium reduction based assay (MTS). Simultaneous MTS measurements confirmed that DGK $\alpha$ silencing affected the viability of SW480 cells only when in 3D (Fig. S2B). These observations indicate that $\mathrm{DGK} \alpha$, whereas dispensable for 2D cell growth, is central for sustaining cancer cell growth in a 3D context.

Cancer cell growth in 3D induces tumorigenic traits that cells display in vivo and are not recapitulated in $2 \mathrm{D}$ culture. The contribution of DGK $\alpha$ to SW480 growth in $3 \mathrm{D}$ suggests that this enzyme could be of interest for cancer therapy. To study the potential of this pathway as a target for pharmacological intervention, we next compared 
the effect of diminishing DGK $\alpha$ protein levels with that produced by a pharmacological inhibitor. We selected the DGK inhibitor II (R59949) that binds to and blocks DGK $\alpha$ catalytic functions [38]. R59949 is reported to be more efficient that the other DGK inhibitor (R59022) in blocking the $\mathrm{Ca}^{2+}$-dependent type I DGK isoforms in vitro, mainly DGK $\alpha$. R59949 inhibits purified DGK $\alpha$ in the low micromolar range [38], but it is highly lipophilic and tends to be sequestered by serum lipids when added to cell cultures [39]. By this reason the drug is used in serum- free culture conditions or, if serum is present, higher concentrations must be used. In this case R59949 may also inhibit other DGK isoforms [40]. 3D assays required long-term cell culture in serum-supplemented media so we first assessed the expression of additional DGK isoforms in SW480 cells.

Data from our related studies indicated that in addition to DGK $\alpha$, SW480 cells also expressed DGK $\zeta$ (Fig. S1B). Due to the lack of efficient commercial antiDGK antibodies, we tested the expression of the remaining
A
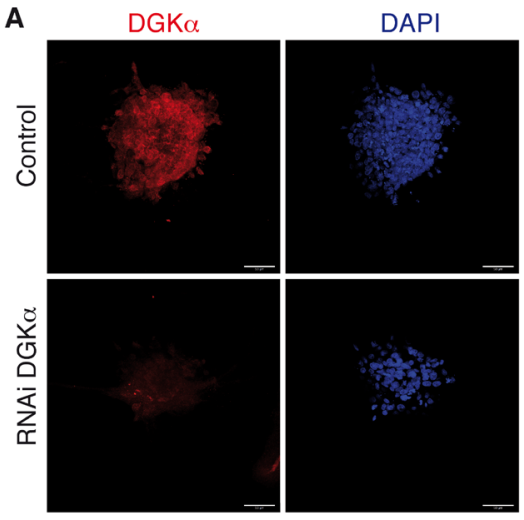

C

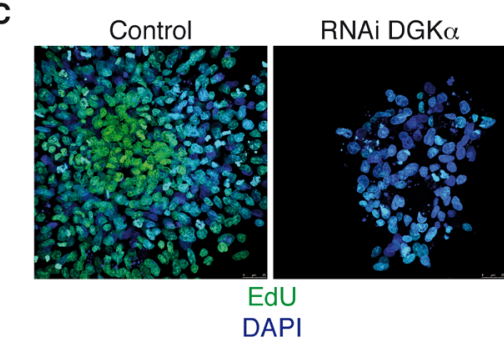

D
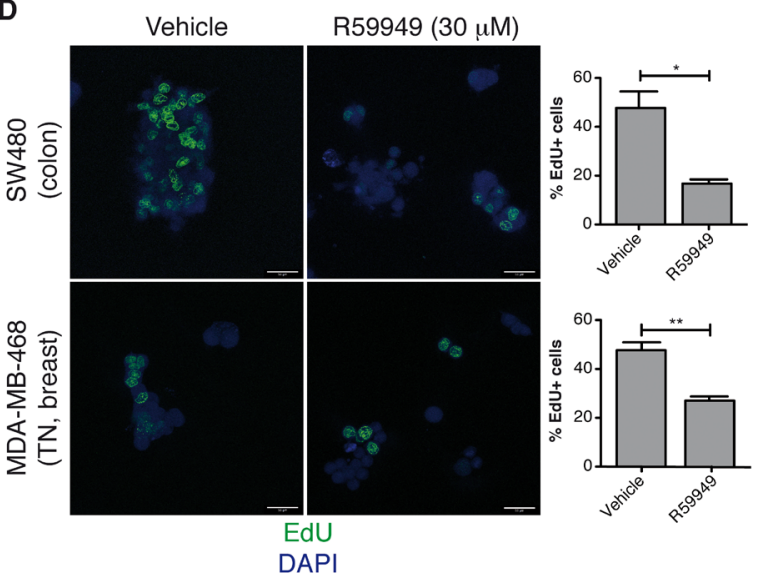

Merge
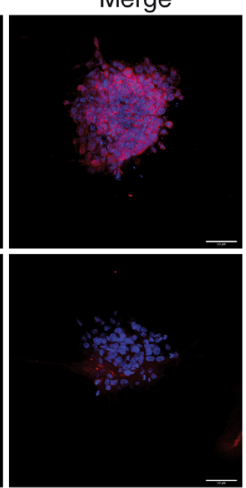

RNAi DGK $\alpha$
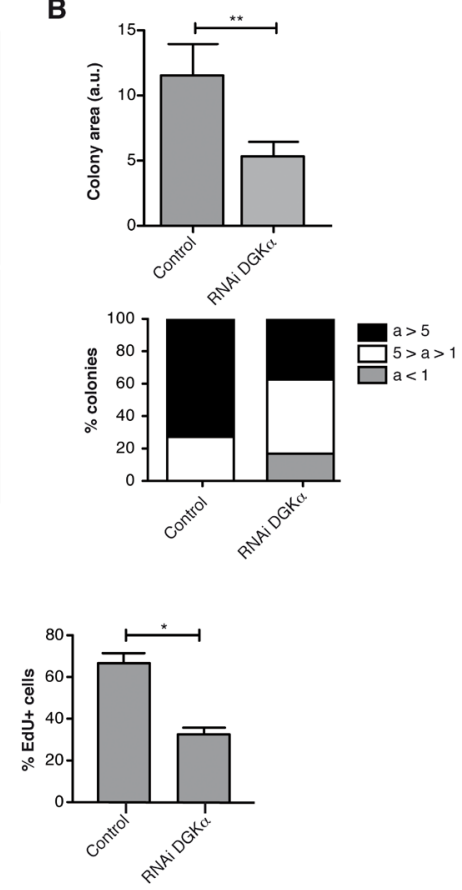

E

Figure 1: DGK $\alpha$ is necessary for cancer cell growth in 3D conditions. (A) Stably control or DGK $\alpha$-depleted SW480 cells were seeded on matrigel and cultured for 6 days. Cells were stained for DGK $\alpha$ and with DAPI. (B) Colony area (a) from control and DGK $\alpha-$ depleted cells was determined using the ImageJ software, and expressed in arbitrary units (a.u.). The mean \pm SEM of the area of each group is shown (top). The area value was classified in 3 categories ( $>>5,5>a>1, a<1$ a. u.), the area distribution is showed for each group (bottom). $\mathrm{n}=50$ colonies in each case. (C) Cell nuclei were stained with DAPI and proliferation inferred by staining with EdU. \% EdU positive cells $($ mean $\pm \mathrm{SEM})$ in the total of DAPI stained cells was determined in several fields of at least 3 different experiments. (D) SW480 and MDAMB-468 cells were seeded on matrigel (4 days) and R59949-treated (48 h). Cells were stained and analyzed as in C. (E) Caco-2 and MCF10 A cells were seeded on matrigel (4 days), R59949-treated (48 h), and stained for actin and with DAPI. A representative field is shown ( $n$ $\geq 3$ independent experiments). A, C, D, bar $=50 \mu \mathrm{m} ; \mathrm{B}$, bar $=25 \mu \mathrm{m}$. 
DGK isoforms by RT-PCR. This analysis indicated that SW480 cells also expressed type II DGK $\delta$ and DGK $\eta$, and type III DGK $\varepsilon$; but not type IV DGK1 or type V DGK $\theta$ (Fig. S3A). To discard that in our experimental conditions, R59949 could inhibit not only DGK $\alpha$, but also some of the other expressed DGK, we determined the efficiency and selectivity of R59949 by comparing its effects over total DGK activity in control and DGK $\alpha$ silenced cells. We have previously used $30 \mu \mathrm{M}$ of the inhibitor to demonstrate the DGK $\alpha$-mediated control of hypoxiainducible factor- $1 \alpha$; this same dose has been reported by other groups to confirm DGK function [41-43]. We thus cultured SW480 cells for $24 \mathrm{~h}$ in complete medium in the presence of R59949 at 15 and $30 \mu \mathrm{M}$. The lower dose had a minimum effect over total DGK activity, whereas $30 \mu \mathrm{M}$ R59949 diminished DGK activity by near 25\%. A similar reduction was observed in cells with DGK $\alpha$ silencing, and in this case R59949 addition did not further affect activity (Fig. S3B).

We next investigated if the R59949-resistant DGK activity in SW480 cells could be ascribed to the DGK $\zeta$ isoform that, as we have previously shown, has a prominent role in controlling total DGK activity in $\mathrm{T}$ cells $[36,44]$. We found that $\mathrm{DGK} \zeta$ contribution was also important in SW480 cells, since its targeting led to a severe reduction in total DGK activity (Fig. S3B). R59949 addition to DGK $\zeta$-silenced cells fully abolished DGK activity, confirming the drug sensitivity of the remaining isoforms, most probably DGK $\alpha$, in these cells. This agrees with previous reports indicating the high sensitivity of DGK $\alpha$ to R59949 [38, 40], and further indicates that this isoform is the main target of R59949 in these cells.

The effect of pharmacological DGK inhibition was next assessed using SW480 cells growing in 3D. As for DGK $\alpha$ depletion, R59949 treatment of matrigel-plated SW480 cells reduced colony formation (Fig 1D, upper panel). Results were similar for the breast cancer cell line MDA-MB-468, which showed spheroid-like growth with grape-like morphology [37] (Fig. 1D, lower panels). Quantification of EdU incorporation confirmed that, as shown for DGK $\alpha$ silenced cells, R59949 treatment diminished proliferation in the two cell lines (Fig. 1D).

Different from these two highly transformed cells, some cell lines form well-organized acinar-like structures that resemble normal epithelia when cultured under 3D conditions [37]. To be appropriate for clinical use, DGK $\alpha$ inhibition should have little or no effect on untransformed cell growth. We next tested the effect of DGK $\alpha$ inhibition on the Caco-2 cell line that, although it is classified as colon cancer, forms acinar-like structures in matrigel culture and is widely used to study colon morphogenesis [45]. R59949-induced DGK $\alpha$ inhibition did not affect the acinar-like morphology of these cells that grew at the same extent that vehicle-treated cells (Fig. 1E, S2C). R59949 had no effect on the polarized growth of MCF-10A cells, a breast-derived cell line that forms organized structures in
3D culture [46], Fig.1E, S2C). These data indicate that the disorganized growth characteristics of transformed cells require DGK $\alpha$.

\section{DGKa depletion impairs tumor growth in vivo}

Silencing of DGK $\alpha$ had no effect on cancer cell growth in 2D culture, at difference from that observed when cells were cultured in 3D. This characteristic suggests that DGK $\alpha$ sustains three-dimensional configuration in vitro, and thus possibly in vivo. We next examined the contribution of DGK $\alpha$ to maintain 3D growth in vivo, using DGK $\alpha$ silenced SW480 colon cancer cells in xenograft assay models. Mice injected with stably silenced DGK $\alpha$ SW480 cells developed tumors, but they appeared later and grew less compared to control cells (Fig. 2A). Tumors generated upon injection of DGK $\alpha$ silenced cells were smaller and weighted $\sim 50 \%$ less than those of control cells (Fig. 2B, C). Western blot analysis of tumor lysates confirmed that DGK $\alpha$ silencing was maintained along the experiment (Fig. 2D).

To evaluate the in vivo potential of pharmacological DGK $\alpha$ targeting, we also determined the effect of the R59949 inhibitor on SW480 cell xenografts. Our group has reported that DGK inhibitors and rapamycin have similar effects over cell proliferation [47]. We thus chose a dose of $10 \mathrm{mg} / \mathrm{kg}$ of the inhibitor; similar to that used for rapamycin in xenograft assays [48]. In a pilot study, intraperitoneal (i.p.) administration of the corresponding volume of DMSO or R59949 in DMSO resulted highly toxic for the mice. We then selected an alternate vehicle for R59949 administration, using the drug in emulsion with $50 \%$ of PEG3000 in PBS. Again i.p. administration of PEG either alone or with R59949 was toxic at long term $(50 \%$ mice from each group died following the second dose of treatment). Finally, R59949 in emulsion with PEG3000 was subcutaneously administrated. Mice were injected with SW480 cells, tumors were let to grow and R59949 was first injected when the tumors reached a volume of approximate $150 \mathrm{~mm}^{3}$. After the initial injection, the inhibitor was continuously injected every 48 $\mathrm{h}$ during 10 days, when tumors in control animals reached the maximal authorized size (Fig. 2E). This treatment was not toxic for the animals, as assessed by the lack of differences in the weight of vehicle and inhibitor treated mice (Fig. S4). R59949-treatment resulted in marked reduction of tumor growth (Fig. 2F). The impairment in tumor growth was statistically significant when the volume of each individual tumor was normalized to that measured prior inhibitor injection (Fig. 2G). Although R59949 treatment did not result in tumor regression, tumors excised from R59949-treated mice were smaller and weighted less than those obtained from vehicletreated mice (Fig. 2H, I). Immunohistochemical analysis revealed reduced Akt phosphorylation and increased cleaved caspase 3 staining in tumors from R59949- 
A

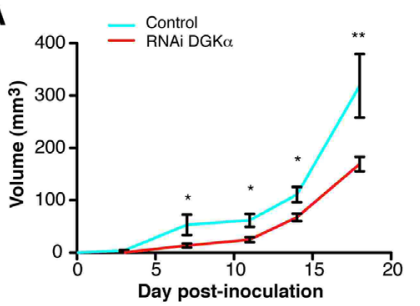

C

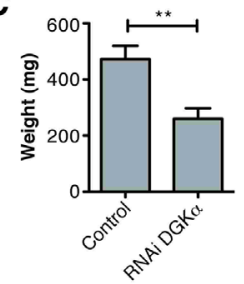

B
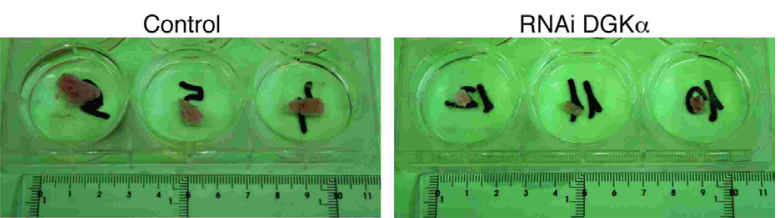

E

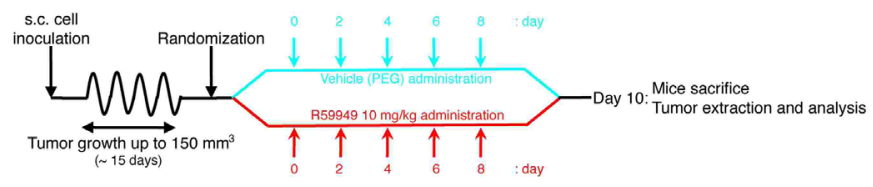

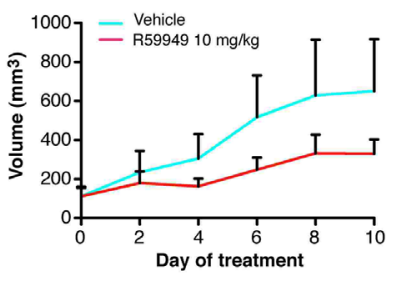

shRNAi:Control DGK $\alpha$

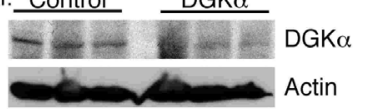

G

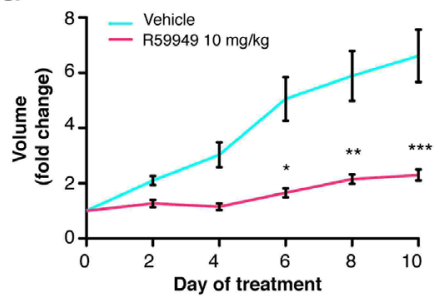

I

H
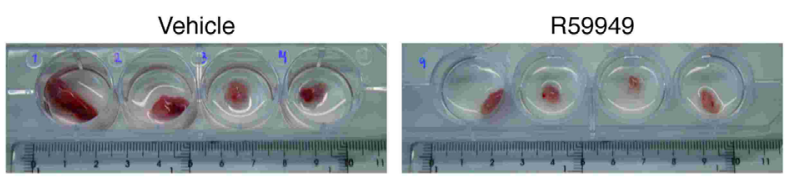

J

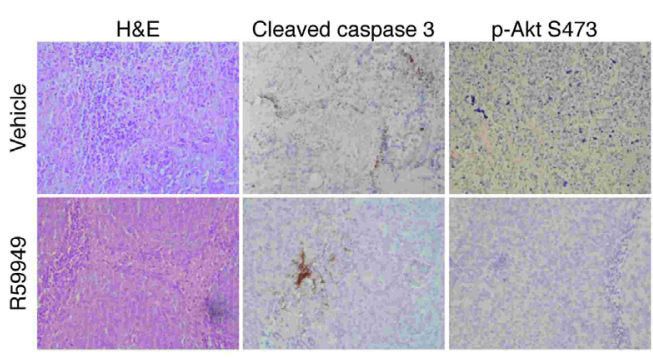

Figure 2: DGKa depletion impairs tumor growth in vivo. Stably infected control or DGKa-depleted SW480 cells $\left(1.5 \times 10^{6}\right)$ were injected s.c. into immunosuppressed mice ( $n=6$ mice/group). (A) Tumor volume was recorded every $48 \mathrm{~h}$. The mean $\pm \mathrm{SEM}$ of the volume of each mice group is shown. (B) After sacrifice, tumors were resected. Tumors of DGK $\alpha$-depleted cells showed a minor size that those from control cells. (C) Tumor weighed (mean \pm SEM). (D) Tumors were lysed in RIPA buffer using a tissue homogenizer and DGK $\alpha$ expression was determined by western blot. Actin was used as loading control (E) Diagram showing the schedule for testing the potential of targeting DGK $\alpha$ in a xenograft assay. SW480 cells $\left(10^{6}\right)$ were injected s.c. into immunosuppressed mice. When tumor volume reached $\sim 150 \mathrm{~mm}^{3}$, mice were divided in two random groups ( $n=6$ mice/group) and treated s.c. with vehicle or R59949 every $48 \mathrm{~h}$ for 10 days. Tumor volume was recorded every $48 \mathrm{~h}$. Mice were sacrificed at day 10 of the treatment. The volume mean (F) and the $x$-fold change (G) mean $\pm \mathrm{SEM}$ in each case are shown. (H, I) After sacrifice the tumors were resected and weighed (mean $\pm \mathrm{SEM}$ ). (J) Tumors were fixed and stained with hematoxylin-eosin and for cleaved caspase 3 and AKT phosphorylated at S473. Each experiment was repeated twice. 
treated mice (Fig. 2J). This analysis strongly suggests that pharmacological DGK $\alpha$ inhibition correlated with impairment of survival pathways and increased apoptosis.

\section{DGKa promotes Src activation}

Our results suggested that DGK $\alpha$ participates in a central node that promotes cancer cell growth in a $3 \mathrm{D}$ context. Culture on matrigel matrices closely mimics the tumor microenvironment and reproduces the cell reprogramming that occurs in vivo. The $D G K \alpha$ promoter contains several regulatory regions that, as shown in $\mathrm{T}$ lymphocytes, modulate transcriptional expression of this enzyme along differentiation stages [14]. We thus investigated if DGK $\alpha$ expression varied as a result of $3 \mathrm{D}$ culture conditions. DGK $\alpha$ mRNA levels were $\sim 3$-fold higher in 3D-cultured SW480 cells compared to 2D culture (Fig. 3A), suggesting 3D-mediated upregulation of DGK $\alpha$ gene expression. We found correlation between increases in DGK $\alpha$ mRNA and in the total amount of DGK $\alpha$ protein (Fig. 3B). Higher DGK $\alpha$ protein levels were also observed for breast tumor-derived cell lines in 3D cultures suggesting a direct correlation with $3 \mathrm{D}$ imposed restrains (Fig. S5). An increase in tyrosine signaling networks, specifically those of the Src family, is a characteristic of colon and breast cancers $[49,50]$, and is critical to sustain
A

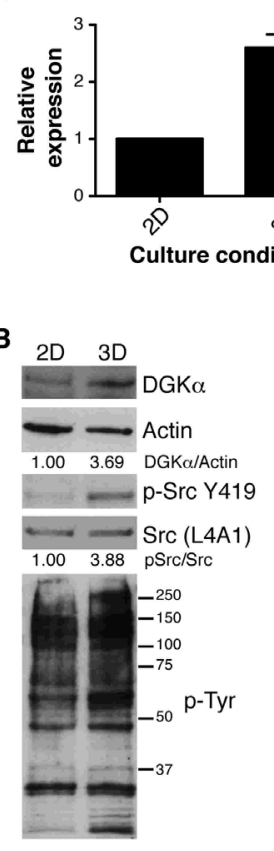

H

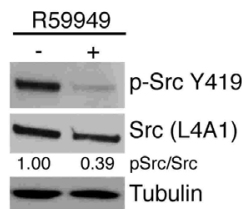

C

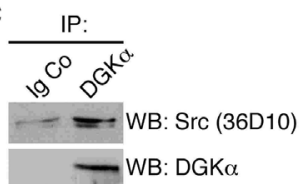

D

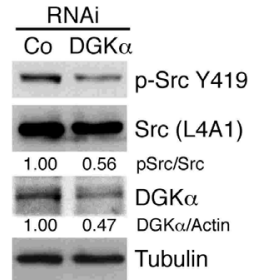

E -+++ myc-DGKa

$++++\operatorname{SrC}$

+ PP2

$+\quad$ R59949

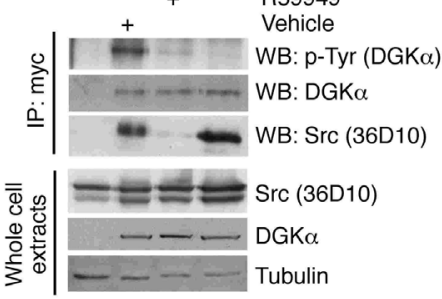

I

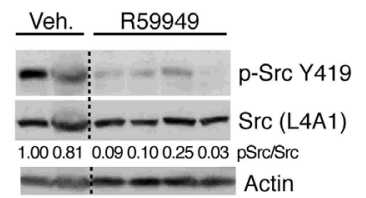

F $\quad$ - WT KD myc-DGKa
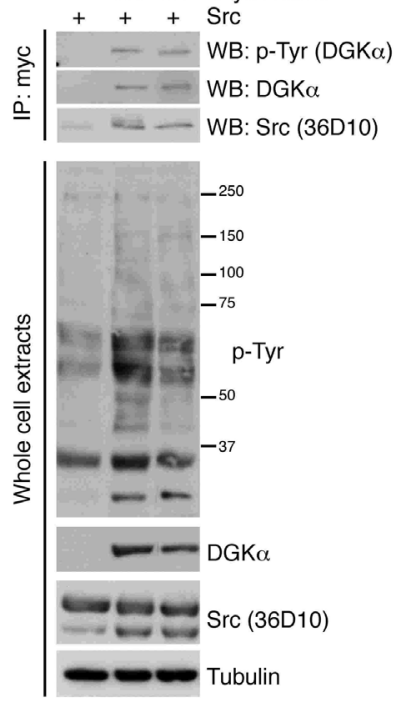

G

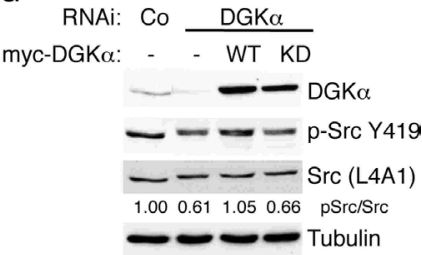

Figure 3: DGKa levels increase in 3D cell cultures and regulate Src signaling networks. SW480 cells were plated at subconfluence ( 2 days) or on matrigel (6 days). (A) RNA was extracted and $D G K \alpha$ analyzed by qPCR. Expression was normalized to that of GAPDH. Mean SEM, $n=3$. (B) DGK $\alpha$ levels, active Src and phosphotyrosine profiles were analyzed by western blot. Total Src and actin were used as loading controls. (C) DGK $\alpha$ immunoprecipitates of SW480 cells were probed for Src association. An unrelated antibody was used as a control. (D) Active Src was evaluated in SW480 cells in exponential growth with reduced DGKa levels. Total Src and tubulin were used as loading controls. (E) Chicken Src and human Myc-DGK $\alpha$ were transiently transfected in HEK-293 cells. After 24 h, cells were treated for $6 \mathrm{~h}$ with R59949 $(20 \mu \mathrm{M})$ or PP2 $(10 \mu \mathrm{M})$, and Myc-DGK $\alpha$ immunoprecipitated to analyze its phosphorylation and association with Src. (F) As in E, but wild type (WT) or kinase-dead (KD) Myc-DGK $\alpha$ were transfected. Phosphotyrosine profiles were analyzed by western blot. (G) SW480 cells were transiently transfected with control, scramble RNAi or targeting DGK $\alpha$. $72 \mathrm{~h}$ post-transfection, the indicated Myc-tagged DGK $\alpha$ constructions were transfected. DGK $\alpha$ levels and active Src were analyzed by western blot. Total Src and actin were used as loading controls. (H, I) Active Src was evaluated in SW480 cells in exponential growth treated with $30 \mu \mathrm{M}$ R59949 (H), or in tumors from R59949-treated mice (I). Total Src, tubulin and actin were used as loading controls. Representative blots are shown $(n \geq 3$ independent experiments, except $n=2$ in I). 
disorganized growth under 3D conditions [51]. SW480 cells cultured in 3D conditions also showed greater Src phosphorylation at Y419, an autophosphorylation site that correlates with optimal Src activity. The increase in Y419 phosphorylation was accompanied by an overall increase in the phosphotyrosine profile (Fig. 3B).

DGK $\alpha$ is known to be a SFK-regulated target in $\mathrm{T}$ cells, as well as in cells of endothelial and epithelial origin. A recombinant GST-DGK $\alpha$ version interacts with and is phosphorylated by recombinant Src [18], and DGK $\alpha$ membrane recruitment and/or activity are induced by SFK-phosphorylation [16, 17]. Other Src effectors, through their association with Src, facilitate an open conformation of the kinase and thus its activation [52]. As increased Src activation in 3D conditions coincided with higher DGKa levels, with no obvious change in Src protein expression, we explored a possible correlation between DGK $\alpha$ upregulation and Src activation. Immunoprecipitation assays showed that endogenous DGK $\alpha$ associated to Src in SW480 cells (Fig. 3C). In these cells, DGK $\alpha$ silencing correlated with a notable reduction in Src Y419 phosphorylation, indicating Src inactivation (Fig. 3D). These observations suggest a mutual regulation between Src and DGK $\alpha$ where, as described for other SFK targets, DGKa interaction with Src facilitates Src activation.

To study in more detail the requirements for Src and DGK $\alpha$ interaction, we overexpressed both proteins in HEK293 cells, which do not express DGK $\alpha$. DGK $\alpha$ was overexpressed as a Myc-tagged protein, to facilitate its immunoprecipitation. As observed for the endogenous proteins, the ectopically expressed DGK $\alpha$ interacted with Src and phosphotyrosine analysis confirmed DGK $\alpha$ phosphorylation (Fig. 3E). Treatment with the Src inhibitor PP2 did not disrupt DGK $\alpha-$ Src interaction, although it abolished tyrosine phosphorylation of DGK $\alpha$. In contrast, treatment with the DGK inhibitor impaired DGK $\alpha-$ Src interaction (Fig. 3E).

To determine if the lack of DGK $\alpha-$ Src interaction was a direct consequence of impaired DGK activity, we examined the interaction of Src with a kinase-deficient DGK $\alpha$ mutant. DGK $\alpha$, rendered inactive by mutation of the conserved, ATP-binding GGDG sequence [53], interacted with Src and was tyrosine phosphorylated (Fig. $3 \mathrm{~F})$. This indicates that DGK $\alpha$ enzymatic activity was dispensable for its interaction with Src. It also suggests that R59949-mediated complex disruption is probably the result of sterically hindrance following inhibitor binding to the DGKa catalytic domain. Total phosphotyrosine profile analysis, however, suggested increased Src activity in cells expressing the active DGK $\alpha$ construct (Fig. 3F), suggesting some contribution of DGK $\alpha$ activity for full Src activation.

Determination of Src activation in HEK293 cells was limited by the high level of ectopically expressed Src as well as by the expression of additional SFK members (see additional bands in HEK293 lysates). We thus reconstituted DGK $\alpha$-silenced SW480 cells with wild type and kinase-dead DGK $\alpha$ versions (Fig. 3G). In these conditions, full Src phosphorylation was only reconstituted by wild type DGKa but not by the kinasedead mutant. This suggests that the enzymatic activity of DGK $\alpha$ is required to achieve complete activation of endogenous Src. R59949 treatment mimicked the effect of DGK $\alpha$ attenuation and resulted in a strong reduction of Src Y419 phosphorylation (Fig. 3H). Finally, the analysis of Src activation in tumor lysates from vehicle- and R59949treated mice bearing SW480 induced tumors, confirmed that treatment with R59949 in vivo also diminished Src activation (Fig. 3I).

\section{DGK $\alpha$ silencing increases cancer cell sensitivity to Src inhibition}

Despite the importance of Src in malignant transformation, monotherapy using Src inhibitors in clinical trials has had only modest results [54]. Aspects of the 3D tumor environment may contribute to limit drug effectiveness including the spatial activation of Src and its regulation by interacting partners. The previous experiments suggested that DGK inhibitor treatment impaired DGK $\alpha$ interaction with Src, so we hypothesized that disruption of DGK $\alpha$-Src complex could not only diminish Src activation, but also enhance its sensitivity to pharmacological inhibitors. Treatment of SW480 cells with the Src inhibitor PP2 diminished Src phosphorylation similar to that observed when treating cells with the DGK inhibitor. The dose of PP2 required to impair Src phosphorylation was reduced when SW480 cells were cotreated with the DGK inhibitor (Fig. 4A). Decreased Src phosphorylation correlated with diminished total tyrosine phosphorylation and reduced expression of Cyclin D3, a cell cycle promoter that is upregulated in many tumor cells [55].

The effect of drug combination was also evaluated in $3 \mathrm{D}$ cultures using cleavage caspase 3 as an indicator of apoptotic cell death. In these experiments PP2 was assayed at $10 \mu \mathrm{M}$, a concentration reported when using 3D conditions to avoid diffusion and lack of effectiveness due to matrix structure [51]. PP2 treatment at this concentration partially reduced $3 \mathrm{D}$ growth and promoted apoptosis of SW480 cells (Fig. 4B, C). R59949 promoted apoptosis to higher extent, independently of PP2 addition (Fig. 4C). Simultaneous addition of the two inhibitors, however, affected colony integrity as denoted by the decrease in the percentage of intact colonies (Fig. 4B and S6A).

Resistance to Src inhibition has been also attributed to the presence of additional oncogenic mutations. Lack of the PTEN phosphatase, a frequent mutation in breast tumors, enhances Akt activation and phosphotyrosine 
signaling, which diminishes the efficacy of drugs that block RTK or SFK [56]. As for SW480 cells, simultaneous treatment of the PTEN negative MDA-MB-468 cells with R59949 and PP2 reduced Src phosphorylation and Cyclin D3 levels (Fig. 4D). Different from that observed in SW480 cells, phosphotyrosine profiles did not decrease accordingly and even some proteins of high molecular weight showed increased phosphorylation (Fig. 4D). PP2 treatment promoted apoptosis of MDA-MB-468 cells grown in matrigel, although, as for SW480 cells, cell death increased if cells were treated with R59949 (Fig. 4E, F). Combination of PP2 with R59949 significantly increased apoptosis compared to individual treatments (Fig. 4F), and also increased the number of colonies with a disintegrated

A

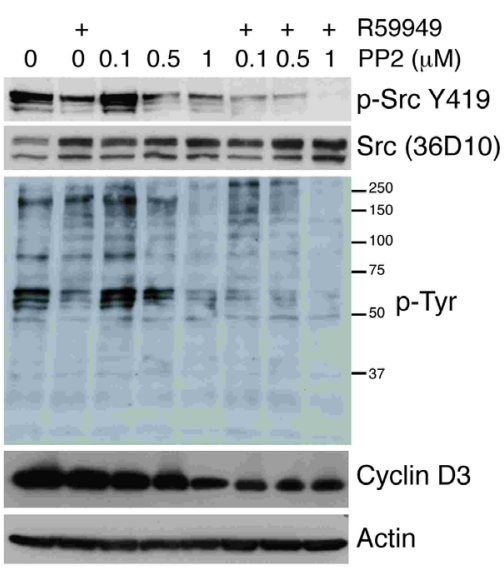

C

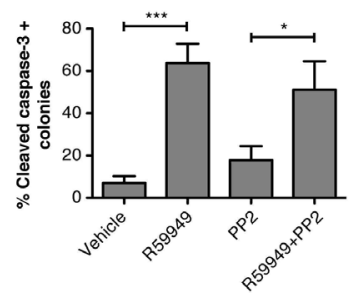

E
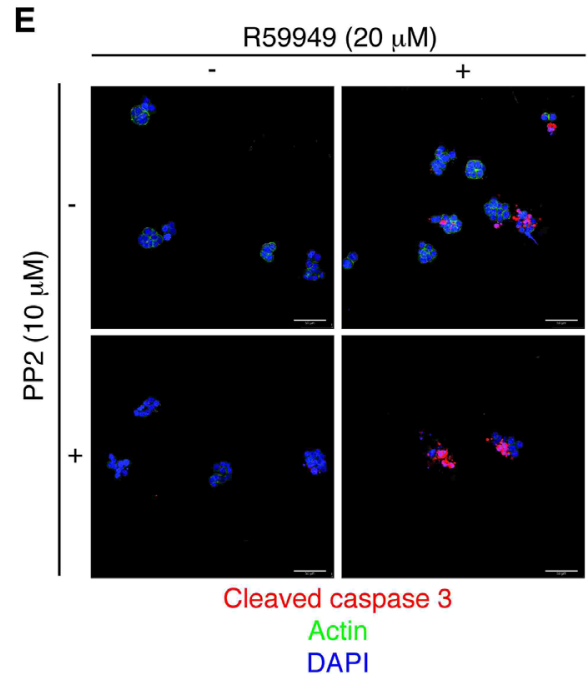

B
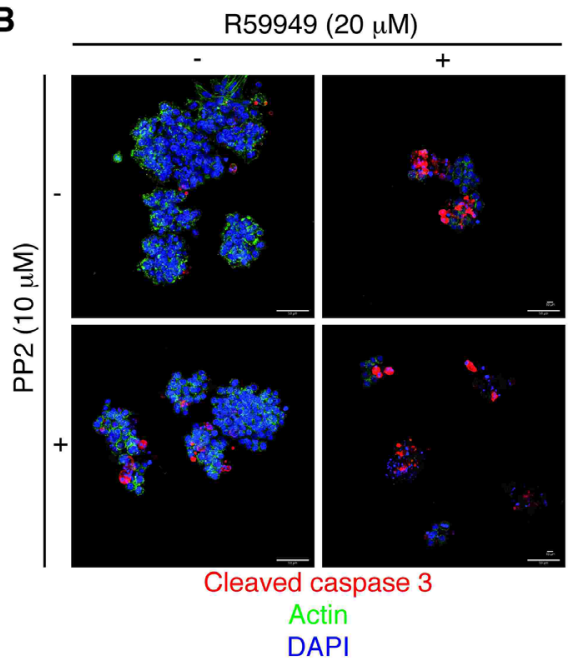

D

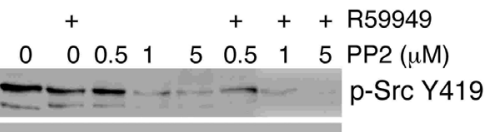

$=-2=\operatorname{Src}(36 \mathrm{D} 10)$

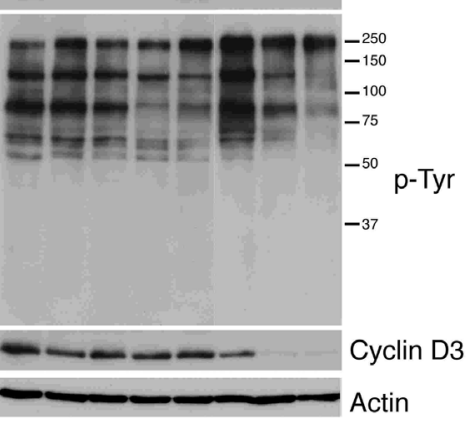

$\mathbf{F}$

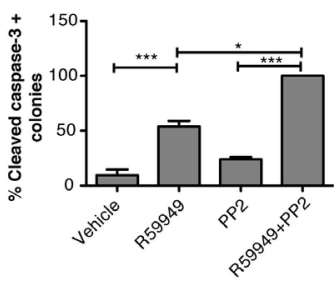

Figure 4: Blocking DGKa augments the sensitivity of cancer cells to Src inhibition. (A) SW480 cells cultured on 2D conditions were treated with the DGK inhibitor $(20 \mu \mathrm{M})$, the indicated doses of PP2, or both $(24 \mathrm{~h})$. Active Src, phosphotyrosine profiles and cyclin D3 levels were analyzed by western blot. Actin was used as loading control. (B) SW480 cells were seeded on matrigel (4 days), and treated with inhibitors $(48 \mathrm{~h}$ ). Cells were fixed and apoptosis evaluated as cleaved caspase 3 staining. Actin and DAPI staining were also performed. (C) The number of caspase positive colonies was determined by examining several fields. The mean \pm SEM of the percentage obtained for each group in different experiments is shown. (D-F) The PTEN-negative cell line MDA-MB-468 was treated with indicated drugs and analyzed as in A, B or C, respectively. Representative blots and fields are shown ( $n \geq 3$ independent experiments). Bar $=50 \mu \mathrm{m}$. 
integrity pattern (Fig. S6B).

Contrary to their previous effects, either individual or combined addition of R59949 and PP2 did not affect spheroid formation when added to 3D cultures of Caco2 or MCF-10A cells (Fig. S7). Our data concur with previous studies showing the synergistic effect of PP2 with other inhibitors acting on the Src pathway in cancer cells, as has been recently described for PKC $\alpha$ inhibitors in breast cancer [57]. These findings strongly suggest that DGK $\alpha$ targeting could render cancer cells sensitive to Src inhibitors.

\section{DGKa participates in the adaptive response of cancer cells to PI3K/Akt inhibition}

$D G K \alpha$ gene expression is strictly controlled by FoxO factors; they promote transcriptional activity by binding to the $D G K \alpha$ distal region [14]. Akt-mediated phosphorylation of FoxO factors leads to their nuclear

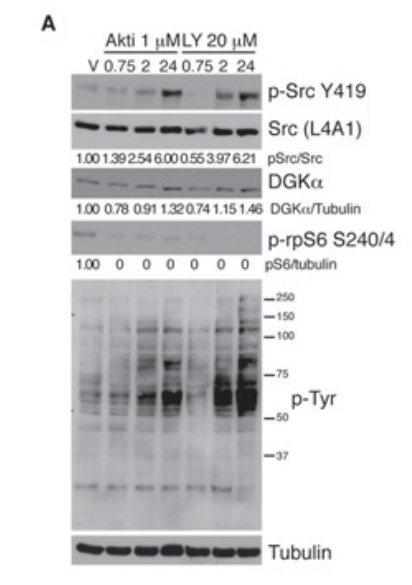

D

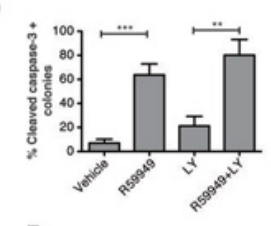

E

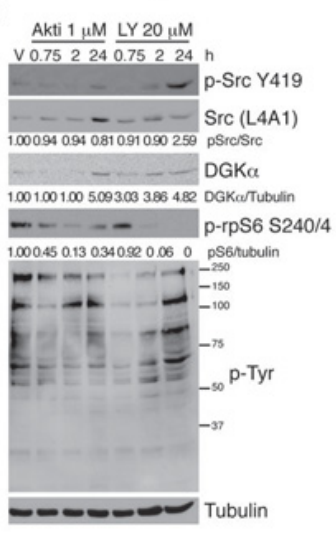

B

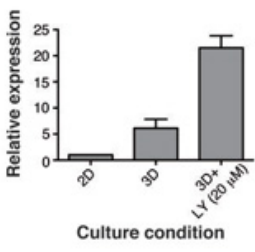

c

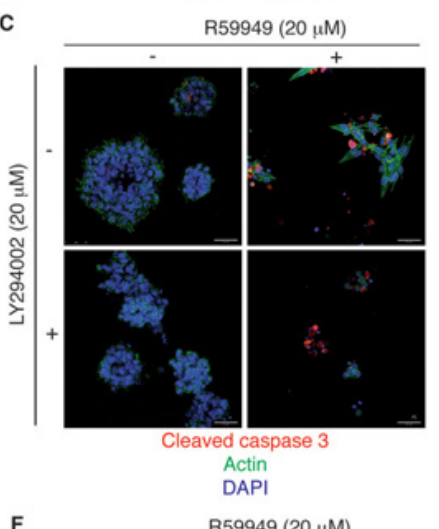

F

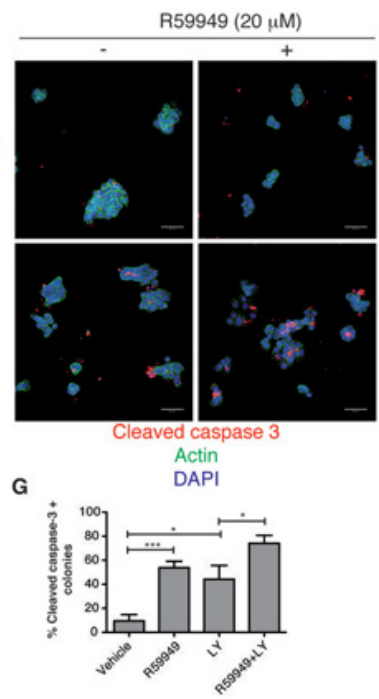

Figure 5: DGKa expression increases after PI3K inhibition. (A) SW480 cells were treated with Akt or PI3K inhibitors for the times indicated. Active Src, phosphotyrosine profiles and DGK $\alpha$ levels were analyzed by western blot. Phosphorylation of rpS6 was used as control of the inhibition. Tubulin was used as loading control. pSrc was normalized to Src expression. DGK $\alpha$ and prpS6 levels were normalized to those of tubulin. (B) SW480 cells were cultured in 2D or in 3D. LY294002 was added to the 3D culture (48 h). RNA was extracted and $D G K \alpha$ analyzed by qPCR. Expression was normalized to that of GAPDH. Mean \pm SEM, $n=3$. (C) SW480 cells were plated on matrigel and treated with R59949, LY294002, or both (48 h). Cells were fixed and stained for actin and caspase 3 and with DAPI. (D) The number of caspase positive colonies was determined by examining several fields from different experiments. The mean $\pm \mathrm{SEM}$ of the percentage obtained for each group in different experiments is shown. (E-G) MDA-MB-468 cells were treated as in A, C or D. In A and E representative blots are shown ( $n=3$ independent experiments). In $\mathrm{C}$ and $\mathrm{F}$ representative fields are shown ( $n \geq 3$ independent experiments). Bar $=50 \mu \mathrm{m}$. 
exit, which blocks their transactivatory function [58]. $\mathrm{DGK} \alpha$ function thus lies downstream of the PI3K/Akt pathway and its function is expected be coupled to the cell differentiation programs controlled by FoxO family. Accordingly, DGK $\alpha$ expression in cytotoxic T populations is repressed by activation of the PI3K/Akt pathway [14]. FoxO factors also control expression of several receptor and non-receptor tyrosine kinases. Noteworthy, cancer cells rely on this mechanism to trigger tyrosine kinase signaling when PI3K or Akt inhibitors are used, which makes them resistant to the deleterious effects of these drugs $[59,60]$.

We tested whether PI3K/Akt inhibition in SW480 colon cancer cells triggered activation of Src and tyrosine signaling, and if this correlated with transcriptional upregulation of DGK $\alpha$. PI3K or Akt-inhibited cell cultures of SW480 cell showed increases in Src activation and in total phosphotyrosine profiles (Fig. 5A). DGK $\alpha$ protein levels increased after $24 \mathrm{~h}$ of treatment, a time in which Src activation reached the maximum grade (Fig. 5A). Since in $3 \mathrm{D}$ culture conditions the expression of DGK $\alpha$ was higher than in 2D, we next determined its levels in this condition after PI3K inhibition. qPCR analysis of $D G K \alpha$ mRNA levels in PI3K/Akt-inhibited 3D cell cultures of SW480 cells showed a 3 - to 5-fold increase in $D G K \alpha$ expression relative to controls (Fig. 5B). By sustaining Src activation, increased DGK $\alpha$ levels might limit the deleterious effect of PI3K/Akt inhibitors on tumor survival. In agreement, combined inhibition of DGK and PI3K diminished cell growth and increased apoptosis more effectively than PI3K inhibition alone (Fig. 5C, D). The combined treatment also led to higher disruption of colony integrity compared to any of the single treatments (Fig. S6A).

Increases in Src activation and $\mathrm{DGK} \alpha$ protein levels were also observed after PI3K/Akt inhibition in MDA-MB-468 cells (Fig. 5E). In these cells the effects were stronger when the PI3K inhibitor was used instead of the Akt inhibitor, probably due to the lack of PTEN. Changes on Src activation where not reflected in these cells in the total phosphotyrosine profile, differently from that observed in SW480 cells. In 3D culture conditions, PI3K inhibition promoted apoptosis at similar extent that R59949 (Fig. 5F, G), although the combined inhibition of DGK and PI3K increased the number of colonies with disintegrated structure (Fig. S6B). Inhibitors treatment did not affect spheroid formation by Caco-2 or MCF-10A cells when added either alone or in combination (Fig. S7).

Together these data suggest that the crosstalk between the PI3K/Akt/FoxO and Src pathways via DGK $\alpha$ provides cancer cells with a mechanism to adapt and subvert the deleterious effects of PI3K/Akt inhibition. DGK $\alpha$ targeting might therefore represent a useful and non-explored approach to combine with and prevent resistance to anti-cancer therapies aimed to inhibit the PI3K/AKT axis.

\section{DISCUSSION}

Improvement of anticancer therapies requires reliable identification of targets with a clear role in cancer cell adaptation to the cues of the tumor microenvironment. Three-dimensional cell culture constitutes a valuable tool for target identification, since it resembles the conditions that cells might encounter in vivo [61]. Compared to 2D, $3 \mathrm{D}$-cultured cells show patent differences not only in morphology, but also in the expression of various receptors and oncogenes, and in the response to drugs [62]. Here we identify DGK $\alpha$ upregulation as part of the reprogramming that occurs when breast and colon cancer cells grow in a 3D microenvironment. In addition, we demonstrate that DGK $\alpha$ silencing or its pharmacological targeting limits cell growth only when cells are 3D-cultured or xenografted in immune-compromised mice, but not during 2D cultures. Our data reinforce previous reports supporting a positive function of DGK $\alpha$ in cancer, and also provide a mechanistic link by showing that DGK $\alpha$ contributes to Src activation. These findings identify DGK $\alpha$ as a component of a positive feedback loop that contributes to Src-regulated functions and as a potential target for the development of anti-tumor therapies

Several reports indicate that DGK $\alpha$ sustains survival of cancer cells, including lymphoma, melanoma and hepatoma [2-4]. DGK $\alpha$ phosphorylation by Src correlates with the activation of its lipid kinase activity $[17,18]$, leading to PA generation. In this study we demonstrate that DGK $\alpha$, in addition to its previous identification as a Src target, may also contribute to enhance Src functions. The mechanisms that control Src hyperactivation in cancer remain unclear [30] although it is becoming apparent that oncogenic Src functions are largely dictated by protein interactions that facilitate/restrict its activation. These modulators include upstream RTK, kinases and phosphatases that regulate Src conformation, as well as substrates that unclamp closed/inactive Src and lead to an open/active state [20, 63-65]. Additionally, Src activity is conditioned by its spatial localization or compartmentalization in distinct membrane microdomains $[66,67]$. The unique features of DGK $\alpha$ might allow it to modulate Src at several levels, and thus contribute to its oncogenic properties.

The correlation between DGK $\alpha$ expression and Src autophosphorylation at Y419 correlates with the well-established mechanism of Src activation as a result of substrate interaction. Src modular structure facilitates activation by its substrates through a sequential mechanism: Src SH3 domain mediates the recognition of targets that contain proline-rich sequences. Subsequent phosphorylation leads to exposure of an additional Src docking site, generally a $\mathrm{SH} 2$ binding motif, promoting an open/active conformation of the kinase $[21,68]$. DGK $\alpha$ does not have a consensus $\mathrm{SH} 3$ interaction motif, but its C-terminal region contains a proline stretch that interacts 
with Src in vitro. This interaction drives subsequent phosphorylation of DGK $\alpha$ at Y335 providing additional anchorage to Src SH2 motif [18]. Our studies suggest that DGK $\alpha$, like FAK and CAS, might belong to the family of Src substrates with capacity to promote Src activation.

The capacity of DGK $\alpha$ to trigger Src activation by means of interaction would be independent of its function as a PA producer. In agreement, we show that a kinase inactive DGK $\alpha$ was still capable to bind Src and become phosphorylated. Nonetheless, reconstitution experiments strongly suggest that DGK $\alpha$ activity contributes to Src activation. In this regard, recent studies have identified motifs for binding of acid lipids, including PA, in the Src unique and SH3 domains [69]. PA binding to Src would thus represent an additional layer of regulation to modify Src conformation and activity. In addition to PA mediated Src regulation, others have shown that DGK $\alpha$-generated PA contributes to the survival and invasive properties of cancer cells by several mechanisms. DGK $\alpha$-derived PA promotes mobilization and membrane tethering of RCP, a modulator of Rab protein trafficking, which is necessary for integrin recycling and cell migration in $\mathrm{p} 53$ mutant background [7]. DGK $\alpha$-PA production activates phosphodiesterase activity, that controls cAMP levels and the expression of cAMP responsive genes critical for cancer cell survival including mTOR and HIF-1 [11].

Our results suggest a model in which DGK $\alpha$ interaction with Src would allow mutual regulation of both kinases in a complex, multilayered process that would enhance PA production and Src activation. A partial contribution of DGK $\alpha$-catalytic activity may help to explain the stronger effects on 3D growth observed following treatment with a pharmacological inhibitor when compared to those obtained after DGK $\alpha$ silencing. Whereas both treatments decrease total DGK activity to a similar extent, we demonstrate that R59949 treatment also promotes disruption of the DGK $\alpha$-Src complex, most probably as a consequence of steric interference. A partial DGK $\alpha$ depletion following genetic silencing (aprox. 60\% of total enzyme) would be less effective than the inhibitor targeting complex formation.

This role for DGK $\alpha$ as a Src modulator helps to understand the stronger addiction for this lipid kinase of transformed cells when growing in 3D compared to non-transformed, acini forming cells. This is likely the consequence of the strict requirement that transformed cells have for Src-mediated regulation of growth and survival pathways in the context of matrix components. It also explains the apparent lack of effect when cells are grown in 2D cultures.

DGK $\alpha$ promotion of Src activation might also explain the higher DGK $\alpha$ levels found in hepatic tumors when compared to untransformed neighboring tissue [4]. DGK $\alpha$ is increased in $20 \%$ of hepatomas, where it is associated with high Ki67 levels and recurrence rate. In these studies, the authors suggest that DGK $\alpha$ promotes
MEK/ERK activation by a Ras-independent mechanism. It is tempting to suggest a function for DGK $\alpha$ promoting Src signaling in this cancer type, since there is mounting evidence of a role for Src in hepatocellular carcinoma development [70].

Our studies define an important contribution of DGK $\alpha$ to Src mediated functions. The increased DGK $\alpha$ expression observed at distinct stages of cancer progression, that is, from initial to metastatic growth [13] correlates with the reported function of Src in metastasis and suggests DGK $\alpha$ upregulation in response to stress conditions, such as limited nutrient availability or chemotherapy treatments. In this latter case, our data demonstrate that DGK $\alpha$ expression, upregulated in response to $\mathrm{PI} 3 \mathrm{~K} / \mathrm{Akt}$ inhibition, contributes to $\mathrm{Src}$ activation, and provide additional proof of DGK $\alpha$ as part of tumor escape mechanisms. In summary, DGK $\alpha$ upregulation in $3 \mathrm{D}$ context links the function of this enzyme to tumor survival and drug resistance mechanisms, and further supports development of new drug therapies based on this lipid kinase.

\section{MATERIALS AND METHODS}

\section{Cell lines and culture}

MCF-10A, HEK293 and SW480 cells were purchased from the ATCC. MDA-MB-468 was kindly donated by Dr. L. Planelles (CNB/CSIC) and Caco-2 by Dr. A. González (CNB/CSIC). SW480 cells were maintained in DMEM (Lonza) supplemented with 10\% FBS (GBio) and $2 \mathrm{mM}$ L-Gln (Gibco). Caco-2 cells were maintained with $1 \mathrm{mM}$ sodium pyruvate (Gibco). MCF10A cells were maintained in DMEM/F12 (Lonza, 1:1, $\mathrm{v} / \mathrm{v}$ ), 5\% horse serum (Gibco), $2 \mathrm{mM}$ L-Gln, insulintransferrin-selenium (Gibco), $500 \mathrm{ng} / \mathrm{ml}$ hydrocortisone (Calbiochem) and $20 \mathrm{ng} / \mathrm{mL}$ epidermal growth factor (EGF, Upstate). MDA-MB-468 cells were cultured in Leibovitz's medium (L15, Lonza). All cell lines were maintained at $37^{\circ} \mathrm{C}$ and $5 \% \mathrm{CO}_{2}$ except MDA-MB-468, which was cultured without $\mathrm{CO}_{2}$ in L15 medium. Identity of the breast-derived cell lines was confirmed by STR genotyping (Genomics Facility, IIB/CSIC, Madrid, Spain).

\section{Antibodies and reagents}

Antibodies to p-Src Y416, Src (clones 36D10 and L4A1), p-rpS6 S240/4, cyclin D3, cleaved-caspase 3 and myc-tag (clone 9B11) were purchased from Cell Signaling. Anti-DGK $\alpha$ was from Abnova, monoclonal anti- $\beta$-actin and $-\alpha$-tubulin antibody from Sigma-Aldrich, and anti-GAPDH from Santa Cruz Biotechnology. Antiphosphotyrosine (4G10) was from Upstate.

Leupeptin and aprotinin were from Roche, growth 
factor reduced-matrigel from BD Biosciences. R59949 (DGK inhibitor II; 3-\{2-(4-[bis-(4-fluorophenyl) methylene]-1-piperidinyl)ethyl\}-2,3-dihydro-2-thioxo4(1H)quinazolinone), PP2, LY294002 and Akt Inhibitor VIII (Akti) were from Calbiochem. All other reagents were from Sigma-Aldrich.

\section{DGK silencing}

DGK-targeting was performed using the human DGK $\alpha$ (nt 1153-1173) and DGK $\zeta$ (nt 2290-2310) validated sequences $[35,36,71]$. For transient silencing the sequences were transfected as dsRNA (Ambion) using oligofectamine (Invitrogen). A scramble dsRNA was used as control (Ambion). Effective DGK depletion was achieved at $72-96 \mathrm{~h}$ post-transfection. After $96 \mathrm{~h}$ the expression was recovered. For stable silencing, $64 \mathrm{pb}$ double strand oligonucleotides, encompassing the corresponding interfering $21 \mathrm{nt}$ sequence and a hairpin structure, were cloned in the pSuperRetro vector (Oligoengine). As control the pSuperRetro construct harboring the homolog specific DGK $\zeta$ mouse sequence was used. This control did not reduce the levels of human DGK $\alpha$ or $\zeta$. SW480 cells were infected using standard protocols with the pSuperRetro-cloned sequencecontaining retroviruses. Cells with the retrovirus insertion were selected by culturing in media with G418 $(800 \mu \mathrm{g} /$ ml) until the control, non-infected cells died ( 1 week). The pools were checked for DGK silencing, maintained in media with G418 $(500 \mu \mathrm{g} / \mathrm{ml})$ and used in the long-term experiments.

\section{Cell drug treatments}

The different inhibitors were added to plated cells in complete media for the indicated time (24 to $48 \mathrm{~h}$ ). For DGK inhibition the DGK inhibitor II (R59949) was used since this drug has been reported by our laboratory and others to be much more potent and specific that DGK inhibitor I [38, 47]. To avoid inactivation of R59949 by the serum present in the culture medium and/or the long times of treatment, inhibitor doses from 15 to $30 \mu \mathrm{M}$ in DMSO were used in the experiments.

\section{DGK assays}

DGK activity was measured using 1,2-dioleoyl (C18:1)-DAG as substrate. Lipid micelles containing the substrate were prepared by sonication of the lipid in the presence of PtdSer (10 min, room temperature (RT)); the final concentration of both lipids in the assay was 2 $\mathrm{mM}$. Cells were lysed by sonication in Tris- $\mathrm{HCl} 50 \mathrm{mM}$ $\mathrm{pH} 7.5$, with protease and phosphatase inhibitors $(20 \mu \mathrm{M}$ leupeptin, $1.5 \mu \mathrm{M}$ aprotinin, $1 \mathrm{mM}$ PMSF, $2 \mathrm{mM}$ sodium fluoride, $40 \mathrm{mM} \beta$-glycerolphosphate and $1 \mathrm{mM}$ sodium orthovanadate). Cell lysates were centrifuged (12000 x g, $15 \mathrm{~min}, 4^{\circ} \mathrm{C}$ ), and $20 \mu \mathrm{g}$ of the resulting supernatant mixed with lipid micelles containing the substrate. The reaction was initiated by addition of reaction mix ( $1 \mathrm{mM}$ ATP, 10 $\mathrm{mM} \mathrm{MgCl} 2,100 \mathrm{mM} \mathrm{NaCl}, 1 \mathrm{mM}$ DTT and $10 \mu \mathrm{Ci}\left[\gamma_{-}{ }^{32} \mathrm{P}\right]$ ATP) and incubated $\left(10 \mathrm{~min}, 25^{\circ} \mathrm{C}\right)$ in a final volume of $50 \mu \mathrm{l}$, and was terminated by addition of $1 \mathrm{~N} \mathrm{HCl}$. Lipids were extracted after addition of $\mathrm{CHCl}_{3} / \mathrm{MeOH}(2: 1 \mathrm{v} / \mathrm{v})$. The organic layer was recovered, dried and applied to silica gel TLC plates, which were developed in a $\mathrm{CHCl}_{3} /$ $\mathrm{MeOH} / 4 \mathrm{M} \mathrm{NH}_{4} \mathrm{OH}$ solvent system (9:7:2 v/v/v), dried, and autoradiographed. A non-radioactive standard of the reaction product was used to identify the lipid of interest.

\section{Cell Proliferation}

The effect of the distinct drugs over cell proliferation was determined by evaluating the cell viability using the Promega Cell Titer cell proliferaton assay and according to the manufacturer instructions. The cells were cultured in 96 well plates in either 2D or 3D conditions. Absorbance was measured at $492 \mathrm{~nm}$ in a Sunrise Tecan instrument.

\section{Expression vectors and transfection}

Myc-DGK $\alpha$ cloned in pMT2 was a kind gift of Dr. A. Graziani (University of Piamonte Orientale, Italy). A kinase-dead version of the enzyme was generated, Gly 434 to Ala, using the Quick-Change mutagenesis kit. Oligonucleotides used were: DGKA-G434Aforw: 5'-TTGCTGTGTGGTGCAGACGGCACAGTA-3', DGKA-G434Arev:5'-TACTGTGCCGCTTGCACCACA CACCAA-3'. Nucleotides underlined encoded for the modified amino acid.

The plasmid encoding Src was generated by cloning chicken Src into pCDNA3. Transfections were performed with Lipofectamine LTX/Plus reagent (Invitrogen).

\section{Western blot}

For lysates, cells were washed in cold PBS, and scraped into ice-cold lysis buffer $(50 \mathrm{mM}$ Hepes $\mathrm{pH} 7.4$, $150 \mathrm{mM} \mathrm{NaCl}, 1 \%$ TritonX-100, 10\% glycerol) with protease and phosphatase inhibitors $(20 \mu \mathrm{M}$ leupeptin, 1.5 $\mu \mathrm{M}$ aprotinin, $1 \mathrm{mM}$ PMSF, $1 \mathrm{mM}$ sodium orthovanadate, $40 \mathrm{mM} \beta$-glycerophosphate, $2 \mathrm{mM} \mathrm{NaF}$ ). Clarified lysates were quantified with the Pierce $660 \mathrm{~nm}$ Protein Assay (Thermo Scientific), denatured in Laemmli buffer, and resolved by PAGE. Proteins were transferred to nitrocellulose membranes (Bio-Rad) and incubated with the indicated antibodies.

To prepare lysates from matrigel, cell cultures were scraped into PBS with $5 \mathrm{mM}$ EDTA, protease and 
phosphatase inhibitors, and matrigel allowed to liquefy $\left(30 \mathrm{~min}, 4^{\circ} \mathrm{C}\right)$. Cells were centrifuged $(2000 \mathrm{xg}, 5 \mathrm{~min}$, $4^{\circ} \mathrm{C}$ ), washed twice in PBS with $5 \mathrm{mM}$ EDTA and processed as above.

\section{Immunoprecipitation}

For protein-protein interaction analysis, cells were lysed $\left(30 \mathrm{~min}, 4^{\circ} \mathrm{C}\right)$ as above. Lysates $(500 \mu \mathrm{g}-1 \mathrm{mg})$ were incubated (overnight, $4^{\circ} \mathrm{C}$ ) with appropriate antibody, followed by $50 \mu \mathrm{l} 50 \%$ protein G-Sepharose slurry (1 $\mathrm{h}, 4^{\circ} \mathrm{C}$ ). Immunoprecipitates were washed thrice in lysis buffer and once with $0.5 \mathrm{M} \mathrm{LiCl}$. Immunoprecipitated proteins were resolved by SDS-PAGE and transferred to nitrocellulose membranes for Western blot analysis.

\section{D cell culture}

$3 \mathrm{D}$ cell culture on matrigel was performed as described [46]. Briefly, $300 \mu \mathrm{l}$ matrigel was added to each well of a 6 -well chamber $\left(10 \mathrm{~cm}^{2}\right.$ surface $)$ and allowed to solidify $\left(20 \mathrm{~min}, 37^{\circ} \mathrm{C}\right)$. Cells were trypsinized, resuspended in assay medium (normal medium with $2.5 \%$ matrigel) and seeded ( 1.5 to $3 \times 10^{3}$ cells $/ \mathrm{cm}^{2}$ ). Assay medium was changed every $48 \mathrm{~h}$, and cells allowed to grow up to 14 days. For inhibitor treatment, cells were allowed to grow for 4 days, and then treated for 2 additional days.

\section{Colony formation assays}

Cells $\left(5 \times 10^{2} /\right.$ well) were seeded in 12 -well plates and allowed to grow for 10 days. Colonies and foci were stained with $0.1 \%$ crystal violet solution in $20 \%$ methanol. After extensive washing, crystal violet was dissolved in $10 \%$ acetic acid, and absorbance measured at $620 \mathrm{~nm}$ in a Sunrise Tecan instrument.

\section{Immunofluorescence}

Cells were plated on matrigel-coated (60-70 $\mu \mathrm{l})$ 8-well chambers (Ibidi) and after treatment as indicated, were fixed in $4 \%$ paraformaldehyde $(10 \mathrm{~min}, \mathrm{RT})$. Cells were permeabilized with $0.5 \%$ Triton X-100 (30 min), blocked with $10 \%$ goat serum, $0.05 \%$ TritonX-100 in TBS $\left(30 \mathrm{~min}, 37^{\circ} \mathrm{C}\right.$ ), and incubated with appropriate primary antibody in incubation buffer $(1 \%$ goat serum in TBS; $3 \mathrm{~h}, 37^{\circ} \mathrm{C}$ ) in a humidified chamber. Secondary antibodies (goat anti-rabbit Alexa Fluor 488 or 594; both from Invitrogen) were added and incubated (1 h, RT). To assess proliferation, EdU (Click-iT EdU Cell Proliferation Assays, Life Technologies) was used as recommended. Finally, samples were incubated with DAPI (Invitrogen, 1:1000, $20 \mathrm{~min}, \mathrm{RT}$ ) and Alexa Fluor 488- or TRITC- conjugated phalloidin (Invitrogen, 1:1000, $20 \mathrm{~min}, \mathrm{RT}$ ), mounted in PBS:glycerol $(1: 1, \mathrm{v} / \mathrm{v})$, and visualized under a Leica TCS SP5 confocal microscope.

\section{Real time PCR}

RNA was extracted from cell cultures using Trizol reagent (Invitrogen). cDNA was synthesized from cell culture-extracted RNA (1 $\mu \mathrm{g})$ after DNase (Invitrogen) treatment and retrotranscription with Random Primers (Applied Biosystems) and SuperScript II Reverse Transcriptase (Invitrogen). qPCR reactions were performed with the Power SYBR Green PCR Master Mix (Applied Biosystems) in $10 \mu \mathrm{l}$ final volume. PCR conditions were as follows: $50^{\circ} \mathrm{C}(10 \mathrm{~min}), 95^{\circ} \mathrm{C}(2 \mathrm{~min})$, 40 cycles at $95^{\circ} \mathrm{C}(15 \mathrm{~s})$ and $60^{\circ} \mathrm{C}(1 \mathrm{~min})$. Reactions were run in triplicate with the Applied Biosystems 7900 HT system. Relative expression of each gene was calculated using the $\Delta \Delta \mathrm{Ct}$ method. GAPDH was used as control. Oligonucleotides used were: DGKAforw: 5'-CAATCACATCTGTGGGTGCGAGGA-3', DGKArev: 5'-TTCCCGCCACTCTTAGGATTGAC-3'; GAPDHforw: 5'-ACAGCCTCAAGATCATCAGCAA-3', GAPDHrev: 5'-ATGGCATGGACTGTGGTCATG-3'.

\section{Xenograft model}

All mouse work was carried out in accordance with a protocol approved by the CNB/CSIC Ethics Committee for Animal Experimentation (CEEA-CNB, no. 090004). SW480-shRNA-control and -shRNA-DGK $\alpha$ cells $(1.5$ $\mathrm{x} 10^{6}$ ) were injected subcutaneously (s.c.) into the flank of female BALB/c SCID mice aged 6-8 weeks. Tumor growth was monitored every two days and volume estimated according to the formula: volume $=\left(a^{2} x b\right) / 2$, where $\mathrm{a}=$ tumor width and $\mathrm{b}=$ tumor length in $\mathrm{mm}$. At the end of the experiment (when control tumors reached $1 \mathrm{~cm}^{3}, \sim 30$ days), mice were sacrificed, tumors extracted and weighed.

To assay the effect of the DGK inhibitor R59949 on in vivo tumor growth, SW480 parental cells $\left(10^{6}\right)$ were injected s.c. into the flank of female mice as above. Pharmacological treatment was initiated when tumors reached $\geq 150 \mathrm{~mm}^{3}$ ( $\sim 15$ days). R59949 was administered s.c. $(10 \mathrm{mg} / \mathrm{kg})$ every $48 \mathrm{~h}$ for 10 days. The tumor volume and weight of each mouse was recorded along the treatment. Mice were sacrificed $48 \mathrm{~h}$ after the last dose. Tumors were weighed and then fixed overnight in paraformaldehyde, followed by dehydration in graded ethanol, and embedded in paraffin for immunohistochemical studies. 


\section{Immunohistochemistry}

Tissue sections were formalin-fixed and paraffinembedded. Sections were prepared for antibody staining as described [72]. Briefly, following deparaffinization and hydration, antigen retrieval was performed in $12.5 \mathrm{mM}$ sodium citrate $\mathrm{pH} 6.0\left(30 \mathrm{~min}, 90^{\circ} \mathrm{C}\right)$. Tissue sections were washed in TBSt (TBS, $0.1 \%$ Tween-20) and blocked with $10 \%$ goat serum ( $1 \mathrm{~h}$, room temperature). Primary antibody was incubated (overnight, $4^{\circ} \mathrm{C}$ ), followed by incubation with HRP-coupled secondary antibody (Dako, 1:200, $2 \mathrm{~h}$, room temperature). Staining was detected with the DAB Peroxidase Substrate Kit (Vector Laboratories), and slides were counterstained with hematoxylin (Fisher Scientific) and mounted in Permount (EMS).

\section{Statistical analyses}

Gel bands were quantified with ImageJ software (NIH). Student's t-test was used to compare data. When variance was significantly different as analyzed with the F-test, Welch's correction was applied. When samples did not fit normality as tested with the Kolmogorov-Smirnov test, the Mann-Whitney test was used. Statistical analysis was done with GraphPad Prism 5 software. When the $\mathrm{p}$-value $<0.05$, differences were considered significant $(*$ $\mathrm{p}<0.05 ; * * \mathrm{p}<0.01 ; * * * \mathrm{p}<0.001)$.

\section{ACKNOWLEDGMENTS}

We thank IM group members for helpful discussion, Dr A González for advice and technical support with xenograft assays, Dr S Gutierrez-Erlandsson for technical support for acquisition of confocal microscope images, and C Mark for excellent editorial assistance. PTA holds a FPU fellowship from the Spanish Ministry of Education, AAF was supported by the Spanish AntiCancer Association (AECC) and the Madrid regional government. This work was supported in part by grants from the Spanish Ministry of Economy and Competitivity (BFU2010-21138), Spanish Ministry of Health (Instituto de Salud Carlos III; RD12/0036/0059), and the Madrid regionalgovernment (IMMUNOTHERCAN S2010/BMD2326) to IM.

\section{Financial interest}

We declare no conflicts of financial interest.

\section{Editorial note}

This paper has been accepted based in part on peerreview conducted by another journal and the authors' response and revisions as well as expedited peer-review in Oncotarget.

\section{REFERENCES}

1. Merida I, Avila-Flores A and Merino E. Diacylglycerol kinases: at the hub of cell signalling. Biochem J. 2008; 409(1):1-18.

2. Bacchiocchi R, Baldanzi G, Carbonari D, Capomagi C, Colombo E, van Blitterswijk WJ, Graziani A and Fazioli F. Activation of alpha-diacylglycerol kinase is critical for the mitogenic properties of anaplastic lymphoma kinase. Blood. 2005; 106(6):2175-2182.

3. Yanagisawa K, Yasuda S, Kai M, Imai S, Yamada $\mathrm{K}$, Yamashita T, Jimbow K, Kanoh $\mathrm{H}$ and Sakane F. Diacylglycerol kinase alpha suppresses tumor necrosis factor-alpha-induced apoptosis of human melanoma cells through NF-kappaB activation. Biochim Biophys Acta. 2007; 1771(4):462-474.

4. Takeishi K, Taketomi A, Shirabe K, Toshima T, Motomura T, Ikegami T, Yoshizumi T, Sakane F and Maehara Y. Diacylglycerol kinase alpha enhances hepatocellular carcinoma progression by activation of Ras-Raf-MEK-ERK pathway. J Hepatol. 2012; 57(1):77-83.

5. Baldanzi G, Pietronave S, Locarno D, Merlin S, Porporato P, Chianale F, Filigheddu N, Cantelmo AR, Albini A, Graziani A and Prat M. Diacylglycerol kinases are essential for hepatocyte growth factor-dependent proliferation and motility of Kaposi's sarcoma cells. Cancer Sci. 2011; 102(7):1329-1336.

6. Filigheddu N, Sampietro S, Chianale F, Porporato PE, Gaggianesi M, Gregnanin I, Rainero E, Ferrara M, Perego B, Riboni F, Baldanzi G, Graziani A and Surico N. Diacylglycerol kinase alpha mediates 17-beta-estradiolinduced proliferation, motility, and anchorage-independent growth of Hec-1A endometrial cancer cell line through the G protein-coupled estrogen receptor GPR30. Cell Signal. 2011; 23(12):1988-1996.

7. Rainero E, Caswell PT, Muller PA, Grindlay J, McCaffrey MW, Zhang Q, Wakelam MJ, Vousden KH, Graziani A and Norman JC. Diacylglycerol kinase alpha controls RCP-dependent integrin trafficking to promote invasive migration. J Cell Biol. 2012; 196(2):277-295.

8. Hao X, Sun B, Hu L, Lahdesmaki H, Dunmire V, Feng Y, Zhang SW, Wang H, Wu C, Fuller GN, Symmans WF, Shmulevich I and Zhang W. Differential gene and protein expression in primary breast malignancies and their lymph node metastases as revealed by combined cDNA microarray and tissue microarray analysis. Cancer. 2004; 100(6):11101122.

9. Marchet A, Mocellin S, Belluco C, Ambrosi A, DeMarchi F, Mammano E, Digito M, Leon A, D'Arrigo A, Lise M and Nitti D. Gene expression profile of primary gastric cancer: towards the prediction of lymph node status. Ann Surg Oncol. 2007; 14(3):1058-1064. 
10. Carter H, Samayoa J, Hruban RH and Karchin R. Prioritization of driver mutations in pancreatic cancer using cancer-specific high-throughput annotation of somatic mutations (CHASM). Cancer Biol Ther. 2010; 10(6):582587.

11. Dominguez CL, Floyd DH, Xiao A, Mullins GR, Kefas BA, Xin W, Yacur MN, Abounader R, Lee JK, Wilson GM, Harris TE and Purow BW. Diacylglycerol kinase alpha is a critical signaling node and novel therapeutic target in glioblastoma and other cancers. Cancer Discov. 2013; 3(7):782-797.

12. McMurray HR, Sampson ER, Compitello G, Kinsey C, Newman L, Smith B, Chen SR, Klebanov L, Salzman P, Yakovlev A and Land H. Synergistic response to oncogenic mutations defines gene class critical to cancer phenotype. Nature. 2008; 453(7198):1112-1116.

13. Merida I, Avila-Flores A, Garcia J, Merino E, Almena M and Torres-Ayuso P. Diacylglycerol kinase alpha, from negative modulation of $\mathrm{T}$ cell activation to control of cancer progression. Adv Enzyme Regul. 2009; 49(1):174-188.

14. Martinez-Moreno M, Garcia-Lievana J, Soutar D, TorresAyuso P, Andrada E, Zhong XP, Koretzky GA, Merida $\mathrm{I}$ and Avila-Flores A. FoxO-dependent regulation of diacylglycerol kinase alpha gene expression. Mol Cell Biol. 2012; 32(20):4168-4180.

15. Cutrupi S, Baldanzi G, Gramaglia D, Maffe A, Schaap D, Giraudo E, van Blitterswijk W, Bussolino F, Comoglio PM and Graziani A. Src-mediated activation of alphadiacylglycerol kinase is required for hepatocyte growth factor-induced cell motility. EMBO J. 2000; 19(17):46144622.

16. Fukunaga-Takenaka R, Shirai Y, Yagi K, Adachi N, Sakai $\mathrm{N}$, Merino E, Merida I and Saito N. Importance of chroman ring and tyrosine phosphorylation in the subtype-specific translocation and activation of diacylglycerol kinase alpha by D-alpha-tocopherol. Genes Cells. 2005; 10(4):311-319.

17. Merino E, Avila-Flores A, Shirai Y, Moraga I, Saito N and Merida I. Lck-dependent tyrosine phosphorylation of diacylglycerol kinase alpha regulates its membrane association in T cells. J Immunol. 2008; 180(9):5805-5815.

18. Baldanzi G, Cutrupi S, Chianale F, Gnocchi V, Rainero E, Porporato P, Filigheddu N, van Blitterswijk WJ, Parolini O, Bussolino F, Sinigaglia F and Graziani A. Diacylglycerol kinase-alpha phosphorylation by Src on Y335 is required for activation, membrane recruitment and $\mathrm{Hgf}$-induced cell motility. Oncogene. 2008; 27(7):942-956.

19. Parsons SJ and Parsons JT. Src family kinases, key regulators of signal transduction. Oncogene. 2004; 23(48):7906-7909.

20. Yeatman TJ. A renaissance for SRC. Nat Rev Cancer. 2004; 4(6):470-480.

21. Guarino M. Src signaling in cancer invasion. J Cell Physiol. 2010; 223(1):14-26.

22. Playford MP and Schaller MD. The interplay between Src and integrins in normal and tumor biology. Oncogene. 2004; 23(48):7928-7946.

23. Aligayer H, Boyd DD, Heiss MM, Abdalla EK, Curley SA and Gallick GE. Activation of Src kinase in primary colorectal carcinoma: an indicator of poor clinical prognosis. Cancer. 2002; 94(2):344-351.

24. Nagaraj NS, Smith JJ, Revetta F, Washington MK and Merchant NB. Targeted inhibition of SRC kinase signaling attenuates pancreatic tumorigenesis. Mol Cancer Ther. 2010; 9(8):2322-2332.

25. Zhang $\mathrm{S}$ and $\mathrm{Yu} \mathrm{D}$. Targeting Src family kinases in anticancer therapies: turning promise into triumph. Trends Pharmacol Sci. 2012; 33(3):122-128.

26. Lowell CA and Soriano P. Knockouts of Src-family kinases: stiff bones, wimpy T cells, and bad memories. Genes Dev. 1996; 10(15):1845-1857.

27. Irby RB, Mao W, Coppola D, Kang J, Loubeau JM, Trudeau W, Karl R, Fujita DJ, Jove R and Yeatman TJ. Activating SRC mutation in a subset of advanced human colon cancers. Nat Genet. 1999; 21(2):187-190.

28. Shalloway D, Coussens PM and Yaciuk P. Overexpression of the c-src protein does not induce transformation of NIH 3T3 cells. Proc Natl Acad Sci U S A. 1984; 81(22):70717075 .

29. Shalloway D, Johnson PJ, Freed EO, Coulter D and Flood WA, Jr. Transformation of NIH 3 T3 cells by cotransfection with c-src and nuclear oncogenes. Mol Cell Biol. 1987; 7(10):3582-3590.

30. Irby RB and Yeatman TJ. Role of Src expression and activation in human cancer. Oncogene. 2000; 19(49):56365642.

31. Debnath J and Brugge JS. Modelling glandular epithelial cancers in three-dimensional cultures. Nat Rev Cancer. 2005; 5(9):675-688.

32. Weigelt $B$ and Bissell MJ. Unraveling the microenvironmental influences on the normal mammary gland and breast cancer. Semin Cancer Biol. 2008; 18(5):311-321.

33. Muranen T, Selfors LM, Worster DT, Iwanicki MP, Song L, Morales FC, Gao S, Mills GB and Brugge JS. Inhibition of $\mathrm{PI} 3 \mathrm{~K} / \mathrm{mTOR}$ leads to adaptive resistance in matrix-attached cancer cells. Cancer Cell. 2012; 21(2):227-239.

34. Park CC, Zhang H, Pallavicini M, Gray JW, Baehner F, Park CJ and Bissell MJ. Betal integrin inhibitory antibody induces apoptosis of breast cancer cells, inhibits growth, and distinguishes malignant from normal phenotype in three dimensional cultures and in vivo. Cancer Res. 2006; 66(3):1526-1535.

35. Alonso R, Mazzeo C, Rodriguez MC, Marsh M, FraileRamos A, Calvo V, Avila-Flores A, Merida I and Izquierdo M. Diacylglycerol kinase alpha regulates the formation and polarisation of mature multivesicular bodies involved in the secretion of Fas ligand-containing exosomes in $\mathrm{T}$ lymphocytes. Cell Death Differ. 2011; 18(7):1161-1173. 
36. Gharbi SI, Rincon E, Avila-Flores A, Torres-Ayuso P, Almena M, Cobos MA, Albar JP and Merida I. Diacylglycerol kinase zeta controls diacylglycerol metabolism at the immunological synapse. Mol Biol Cell. 2011; 22(22):4406-4414.

37. Kenny PA, Lee GY, Myers CA, Neve RM, Semeiks JR, Spellman PT, Lorenz K, Lee EH, Barcellos-Hoff MH, Petersen OW, Gray JW and Bissell MJ. The morphologies of breast cancer cell lines in three-dimensional assays correlate with their profiles of gene expression. Mol Oncol. 2007; 1(1):84-96.

38. Jiang Y, Sakane F, Kanoh H and Walsh JP. Selectivity of the diacylglycerol kinase inhibitor 3-[2-(4-[bis-(4-fluorophenyl) methylene]-1-piperidinyl)ethyl]-2, 3-dihydro-2-thioxo4(1H)quinazolinone (R59949) among diacylglycerol kinase subtypes. Biochem Pharmacol. 2000; 59(7):763-772.

39. Outram SV, Crompton T, Merida I, Varas A and Martinez AC. Diacylglycerol kinase alpha activity promotes survival of CD4+ $8+$ double positive cells during thymocyte development. Immunology. 2002; 105(4):391-398.

40. Sato M, Liu K, Sasaki S, Kunii N, Sakai H, Mizuno H, Saga $\mathrm{H}$ and Sakane F. Evaluations of the selectivities of the diacylglycerol kinase inhibitors R59022 and R59949 among diacylglycerol kinase isozymes using a new non-radioactive assay method. Pharmacology. 2013; 92(1-2):99-107.

41. Aragones J, Jones DR, Martin S, San Juan MA, Alfranca A, Vidal F, Vara A, Merida I and Landazuri MO. Evidence for the involvement of diacylglycerol kinase in the activation of hypoxia-inducible transcription factor 1 by low oxygen tension. J Biol Chem. 2001; 276(13):10548-10555.

42. Temes E, Martin-Puig S, Acosta-Iborra B, Castellanos MC, Feijoo-Cuaresma M, Olmos G, Aragones J and Landazuri MO. Activation of HIF-prolyl hydroxylases by R59949, an inhibitor of the diacylglycerol kinase. J Biol Chem. 2005; 280(25):24238-24244.

43. Kim KS, Rajagopal V, Gonsalves C, Johnson C and Kalra VK. A novel role of hypoxia-inducible factor in cobalt chloride- and hypoxia-mediated expression of IL-8 chemokine in human endothelial cells. J Immunol. 2006; 177(10):7211-7224.

44. Gharbi SI, Avila-Flores A, Soutar D, Orive A, Koretzky GA, Albar JP and Merida I. Transient PKCalpha shuttling to the immunological synapse is governed by DGKzeta and regulates L-selectin shedding. J Cell Sci. 2013; 126(Pt 10):2176-2186.

45. Magudia K, Lahoz A and Hall A. K-Ras and B-Raf oncogenes inhibit colon epithelial polarity establishment through up-regulation of c-myc. J Cell Biol. 2012; 198(2):185-194.

46. Debnath J, Muthuswamy SK and Brugge JS. Morphogenesis and oncogenesis of MCF-10A mammary epithelial acini grown in three-dimensional basement membrane cultures. Methods. 2003; 30(3):256-268.

47. Flores I, Casaseca T, Martinez AC, Kanoh H and Merida
I. Phosphatidic acid generation through interleukin 2 (IL2)-induced alpha-diacylglycerol kinase activation is an essential step in IL-2-mediated lymphocyte proliferation. J Biol Chem. 1996; 271(17):10334-10340.

48. Sarbassov DD, Ali SM, Sengupta S, Sheen JH, Hsu PP, Bagley AF, Markhard AL and Sabatini DM. Prolonged rapamycin treatment inhibits mTORC2 assembly and Akt/ PKB. Mol Cell. 2006; 22(2):159-168.

49. Hochgrafe F, Zhang L, O'Toole SA, Browne BC, Pinese M, Porta Cubas A, Lehrbach GM, Croucher DR, Rickwood D, Boulghourjian A, Shearer R, Nair R, Swarbrick A, Faratian D, Mullen P, Harrison DJ, et al. Tyrosine phosphorylation profiling reveals the signaling network characteristics of Basal breast cancer cells. Cancer Res. 2010; 70(22):93919401.

50. Malek RL, Irby RB, Guo QM, Lee K, Wong S, He M, Tsai J, Frank B, Liu ET, Quackenbush J, Jove R, Yeatman TJ and Lee NH. Identification of Src transformation fingerprint in human colon cancer. Oncogene. 2002; 21(47):72567265.

51. Arias-Romero LE, Saha S, Villamar-Cruz O, Yip SC, Ethier SP, Zhang ZY and Chernoff J. Activation of Src by protein tyrosine phosphatase 1B Is required for ErbB2 transformation of human breast epithelial cells. Cancer Res. 2009; 69(11):4582-4588.

52. Pellicena P and Miller WT. Processive phosphorylation of p130Cas by Src depends on SH3-polyproline interactions. J Biol Chem. 2001; 276(30):28190-28196.

53. Sanjuan MA, Jones DR, Izquierdo M and Merida I. Role of diacylglycerol kinase alpha in the attenuation of receptor signaling. J Cell Biol. 2001; 153(1):207-220.

54. Puls LN, Eadens M and Messersmith W. Current status of SRC inhibitors in solid tumor malignancies. Oncologist. 2011; 16(5):566-578.

55. Zhang Q, Sakamoto K and Wagner KU. D-type Cyclins are important downstream effectors of cytokine signaling that regulate the proliferation of normal and neoplastic mammary epithelial cells. Mol Cell Endocrinol. 2014; 382(1):583-592.

56. Zhang S, Huang WC, Li P, Guo H, Poh SB, Brady SW, Xiong Y, Tseng LM, Li SH, Ding Z, Sahin AA, Esteva FJ, Hortobagyi GN and Yu D. Combating trastuzumab resistance by targeting SRC, a common node downstream of multiple resistance pathways. Nat Med. 2011; 17(4):461469.

57. Tan M, Li P, Sun M, Yin G and Yu D. Upregulation and activation of PKC alpha by ErbB2 through Src promotes breast cancer cell invasion that can be blocked by combined treatment with PKC alpha and Src inhibitors. Oncogene. 2006; 25(23):3286-3295.

58. Tzivion $\mathrm{G}$, Dobson $\mathrm{M}$ and Ramakrishnan G. FoxO transcription factors; Regulation by AKT and 14-3-3 proteins. Biochim Biophys Acta. 2011; 1813(11):19381945. 
59. Chandarlapaty S, Sawai A, Scaltriti M, RodrikOutmezguine V, Grbovic-Huezo O, Serra V, Majumder PK, Baselga J and Rosen N. AKT inhibition relieves feedback suppression of receptor tyrosine kinase expression and activity. Cancer Cell. 2011; 19(1):58-71.

60. Garrett JT, Chakrabarty A and Arteaga CL. Will PI3K pathway inhibitors be effective as single agents in patients with cancer? Oncotarget. 2011; 2(12):1314-1321.

61. Breslin S and O'Driscoll L. Three-dimensional cell culture: the missing link in drug discovery. Drug Discov Today. 2013; 18(5-6):240-249.

62. Smalley KS, Lioni M and Herlyn M. Life isn't flat: taking cancer biology to the next dimension. In Vitro Cell Dev Biol Anim. 2006; 42(8-9):242-247.

63. Ishizawar R and Parsons SJ. c-Src and cooperating partners in human cancer. Cancer Cell. 2004; 6(3):209-214.

64. Okada M. Regulation of the SRC family kinases by Csk. Int J Biol Sci. 2012; 8(10):1385-1397.

65. Nunes-Xavier CE, Martin-Perez J, Elson A and Pulido R. Protein tyrosine phosphatases as novel targets in breast cancer therapy. Biochim Biophys Acta. 2013; 1836(2):211226.

66. Oneyama C, Ino T, Saito K, Suzuki K, Ogawa A and Okada M. Transforming potential of Src family kinases is limited by the cholesterol-enriched membrane microdomain. Mol Cell Biol. 2009; 29(24):6462-6472.

67. Tu C, Ortega-Cava CF, Winograd P, Stanton MJ, Reddi AL, Dodge I, Arya R, Dimri M, Clubb RJ, Naramura M, Wagner KU, Band V and Band H. Endosomal-sorting complexes required for transport (ESCRT) pathwaydependent endosomal traffic regulates the localization of active Src at focal adhesions. Proc Natl Acad Sci U S A. 2010; 107(37):16107-16112.

68. Harrison SC. Variation on an Src-like theme. Cell. 2003; 112(6):737-740.

69. Perez Y, Maffei M, Igea A, Amata I, Gairi M, Nebreda AR, Bernado P and Pons M. Lipid binding by the Unique and $\mathrm{SH} 3$ domains of c-Src suggests a new regulatory mechanism. Sci Rep. 2013; 3:1295.

70. Liu H, Xu J, Zhou L, Yun X, Chen L, Wang S, Sun L, Wen $\mathrm{Y}$ and $\mathrm{Gu}$ J. Hepatitis B virus large surface antigen promotes liver carcinogenesis by activating the Src/PI3K/ Akt pathway. Cancer Res. 2011; 71(24):7547-7557.

71. Avila-Flores A, Santos T, Rincon E and Merida I. Modulation of the mammalian target of rapamycin pathway by diacylglycerol kinase-produced phosphatidic acid. J Biol Chem. 2005; 280(11):10091-10099.

72. Carracedo A, Ma L, Teruya-Feldstein J, Rojo F, Salmena L, Alimonti A, Egia A, Sasaki AT, Thomas G, Kozma SC, Papa A, Nardella C, Cantley LC, Baselga J and Pandolfi PP. Inhibition of mTORC1 leads to MAPK pathway activation through a PI3K-dependent feedback loop in human cancer. J Clin Invest. 2008; 118(9):3065-3074. 